\title{
Multi-criteria evaluation of site selection for smart community demonstration projects
}

\author{
Ming-Shiu Sung*, Shen-Guan Shih, Yeng-Horng Perng
}

National Taiwan University of Science and Technology, Taipei City, Taiwan; sgshih@mail.ntust.edu.tw (S.G.S.); perng@mail.ntust.edu.tw (Y.H.P.)

* Correspondence: misuui@hotmail.com ; Tel:0958513101 ; Fax: 02-22454982

\begin{abstract}
Some researchers in Taiwan argue that the current mechanism by which government subsidies are allocated for smart city demonstration projects warrants improvement. A comprehensive literature review determined that the development potential of smart cities should be prioritized in site selection for such demonstration projects. This study developed an evaluation framework on the basis of multi-criteria evaluation methods to enable the identification of suitable smart community demonstration sites. Evaluation criteria were first identified through the Delphi method. Next, the weights of each criterion were derived through the analytic hierarchy process. Furthermore, the capability of the proposed evaluation model was determined through simulation testing.
\end{abstract}

Keywords: Smart city; demonstration project; multi-criteria evaluation; Delphi method; analytic hierarchy process

\section{Introduction}

In Taiwan, some researchers argue that the current mechanism by which government subsidies are allocated for smart city demonstration projects warrants improvement. A comprehensive literature review determined that the development potential of smart cities should be prioritized in site selection for such demonstration projects. This study developed an evaluation framework on the basis of multi-criteria evaluation methods to enable the identification of suitable demonstration sites. An evaluation framework was first developed through the literature review, after which evaluation criteria were identified through a review of smart city projects implemented in Europe. Moreover, the differences between the proposed evaluation framework and the current system were examined. The proposed evaluation framework was assessed through two steps. Evaluation criteria were first identified through the Delphi method. Next, the weights of each criterion were derived through the analytic hierarchy process. Furthermore, the capability of the proposed evaluation model was determined through simulation testing. Four demonstration sites were subjected to simulation: Taipower Smart Community, National Yunlin University of Science and Technology, Taichung Creative Cultural Park, and the Asia New Bay Area in Kaohsiung (hereafter the Asia New Bay Area). The findings are expected to facilitate the selection of future smart community demonstration sites.

\section{Theoretical background}

\subsection{Smart city}

Smart cities are characterized as the emergent future versions of a city, running in part on streams of data that continuously flow between physical objects, actors, and institutions that respectively define, inhabit, and govern cities (Batty 2020; Batty et al. 2012; Townsend 2013; Kandt, J., and M. Batty. 2021).

The smart city agenda builds upon and extends a longer history of computationally networked urbanism that has been in progress from the early 1970s and variously labelled 'wired cities' (Dutton et al. 1987), 'cyber cities' (Graham and Marvin 1999), 'digital cities' 
(Ishida and Isbister 2000), 'intelligent cities' (Komninos 2002), 'sentient cities' (Shepard 2011), among others (Kitchin 2014; Willis and Augiri 2018) and overlap with other popular, current city framings (e.g., resilient cities, sustainable cities, safe cities, eco-cities). In contrast to earlier formulations of networked urbanism, smart cities as a concept, aspiration, and an assemblage of products, rapidly gained traction in industry, government and academia from the late 2000s onwards to become a global urban agenda (Willis and Augiri 2018)( Kitchin, R., Coletta, C., Evans, L. and Heaphy, L. 2018).

The international evaluation team is the Austria-Vienna University of Technology Regional Science Center, the Geography Department of the University of Ljubljana, and the Netherlands-Tiff Delft University of Technology is composed of three research units in cooperation with the Institute of Urban Mobility in Architecture. The team believes that the definition of a smart city must be defined in Smart Economy, Smart People, Smart Governance, Smart Mobility, Smart Environment, and Smart Living. All aspects perform well. (Institute for Information Industry,2014). According smart city of the evaluation criteria, that "community cohesion" is the part of humanistic attributes, such as "A Smart City is a city well performing built on the 'smart' combination of endowments and activities of self-decisive, independent and aware citizens" (Analisa Cocchia ,2014).

\subsection{Smart city projects}

The concept of experimental cities, a living lab operates in a real-life context and adopts a user-centric approach in that users participate in the innovation and development of new business service models. In other words, users are present in every stage of product development and contribute to the innovation of a product or service by drawing from their own life or social experiences. Products or services developed in this manner satisfy the needs of the public and more closely align with their everyday realities. Studies have reported that user participation in the innovation development process of a product or service corresponds to a lower likelihood of market failure (Chesbrough 2003; Gassmann and Enkel 2004; Schuth, Balog, and Kelly 2015).

Smart city demonstration project sites are sites selected for smart city model experiments or smart service model experiments. These sites are used to conduct experimental activities, such as experiential activities for daily life services, infrastructure testing, and operating procedure simulations. The primary selection criteria for identifying the most suitable sites for such projects are the sustainable intelligentization needs associated with the sites and the site participants' willingness to cooperate with project implementation. Other selection criteria include basic infrastructure, as well as the sustainable smart service development of the sites and resources to be invested into the sites. By performing an integrated evaluation of the criteria, researchers can select the site that best matched their objectives and needs (Institute for Information Industry 2015; Architecture and Building Research Institute, Ministry of the Interior 2015).

For example, Dameri (2014) used a formal organization/quadruple helix model to explore smart city governance in Genoa. Specifically, key actors and participation were adopted as variables to compare smart city governance in Genoa and Amsterdam. For Genoa, participation was set as open, whereas for Amsterdam, it was set as closed(Dameri, R. P. 2014 ; Dameri, R. P., and C. Rosenthal-Sabroux, eds. 2014) .We can compare the key players in Genova and in Amsterdam. There are some similarities and some differences. Both the cities have a top-down process, driven by a public body, that is, the Municipality. It suggests that a smart city project is complex, requires important plans and funding and it is necessary to well define its development paths to obtain effective results. However, Amsterdam choose a hierarchical, closed governance model, Genova a flat and open one. Genova, even if strongly focused on smart initiatives interesting physical infrastructures and less involved in digital initiatives, considers the citizens and not-for-profit associations like key players for its success, and a formal, democratic organization of GSCA like a crucial instrument to drive the development of Genova smart city gaining the higher consensus. At present, it is early to assess which is the best solution; 
but perhaps all of them are the best solution for each city. Indeed, a smart city comprehensive project, involving completely a city and aiming at transforming its profile, needs to be city-specific and harmonized with the culture and the other characteristics of the urban area. (R. P. Dameri ,2014).

\subsection{Multi-criteria evaluation (MCE)}

Multiple criteria decision-making (MCDM), which originated from Koopmans' concept of efficient vectors (Zeleny 1982), has been used by various scholars and decision makers to address problems related to design, selection, and evaluation. Using multiple criteria as the basis of evaluation, decision makers express their preference structure. They then determine the noninferior solutions or the ordering of the alternative solutions in terms of their suitability. MCDM can help decision makers analyze and rank their limited solutions according to their pros and cons, allowing the ideal solution to be determined (Hwang and Yoon 1981; Tsou 2013). Common MCDM methods include the simple multiattribute ranking technique (Edwards 1977; Edwards and Barren 1994) and the analytic hierarchy process (AHP; Satty 1980).

Among the numerous approaches available for conflict management, MCDM is one of the most widely used. In this approach, practical problems are often characterized by several non-commensurable and competing (conflicting) criteria, and there is no solution satisfying all the criteria simultaneously. Thus, a compromise solution for problems with conflicting criteria should be determined to help decision makers reach a final decision. The MCDM procedure applied in this paper consists of the following steps: (a) Establishing system evaluation criteria (multiple) that relate system capabilities to goals; (b) Developing (designing) alternative systems for attaining the goals (generating alternatives); (c) Evaluating alternatives in terms of criteria (the values of the criterion functions); (d) Applying a normative multicriteria analysis method (such as compromise ranking); (e) Accepting one alternative as "optimal" (preferred); and (g) If the final solution is not accepted, then gather new information and go into the next iteration of multicriteria optimization.

Steps (a) and (e) are performed at the decision (upper) level, where decision makers have a central role. Other steps are mostly mechanical tasks. Alternatives can be generated and their feasibility can be tested using mathematical models, physical models, and/or by experiments on the existing system or other similar systems. Generating alternatives may be a very complex process, there is no general procedure or model, and no mathematical procedure could replace the human creativity in generating and evaluating alternatives. Constraints are seen as high-priority objectives, and they must be considered and satisfied in the alternatives generating process. Assuming that each alternative is evaluated according to each criterion $\mathrm{f}$ unction, the compromise ranking method could be applied to determine a compromise solution, helping the decision makers to reach final decision. Compromise solution is a feasible solution which is the "closest" to the ideal. A compromise means an agreement established by mutual concessions. The compromise ranking method (known as VIKOR) has been introduced as one applicable technique to implement within MCDM. The main features of this method are presented in Appendix B. By the compromise ranking method a compromise solution is determined which could be accepted by the decision makers because it provides a maximum "group utility" of the "majority" (with measure S; representing "concordance"), and a minimum of individual regret for the "opponent" (with measure R; representing "discordance"). The VIKOR algorithm determines the weight stability intervals for the obtained compromise solution with the "input"' weights given by experts (Opricovic, 1998; Gwo-Hshiung Tzeng 2002).

\section{MCE model construction}

3.1. Key factor framework of the evaluation criteria 
Multicriteria evaluation of a smart city subsidization plan requires the weights of various factors to be determined in advance. These factors include who (ability in project implementation), what (project scope), where (smart community), and sustainability (financial self-reliance). According international retrospective indicators and domestic predicative indicators, the MCE of smart city demonstration projects in this study involved five dimensions, namely environment, governance, mobility, people, and feedback, according to which evaluation indexes were configured (Table 1).

Table 1. MCE framework for evaluating smart city demonstration projects.

\begin{tabular}{|c|c|c|c|c|c|c|c|c|c|c|}
\hline $\begin{array}{l}\text { Evaluation } \\
\text { dimension }\end{array}$ & \multicolumn{2}{|c|}{ A. Environment } & \multicolumn{2}{|c|}{ B. Governance } & \multicolumn{2}{|c|}{ C. Mobility } & \multicolumn{2}{|c|}{ D. People } & \multicolumn{2}{|c|}{ E. Feedback } \\
\hline \multirow[t]{2}{*}{ Index group } & \multicolumn{2}{|c|}{ Indexes $\mathrm{A}-1$ to $\mathrm{A}-3$} & \multicolumn{2}{|c|}{ Indexes B-1 and B-2 } & \multicolumn{2}{|c|}{ Indexes C-1 and C-2 } & \multicolumn{2}{|c|}{ Indexes D-1 and D-2 } & \multicolumn{2}{|c|}{ Indexes E-1 to E-4 } \\
\hline & A-1 & $1-3$ & B-1 & $1-2$ & C-1 & $1-4$ & D-1 & $1-3$ & E-1 & $1-3$ \\
\hline \multirow[t]{2}{*}{ Index label } & A-2 & $1-3$ & B-2 & $1-4$ & $\mathrm{C}-2$ & $1-2$ & D-2 & $1-3$ & E-2 & $1-4$ \\
\hline & A-3 & $1-3$ & & & & & & & E-3 & $1-2$ \\
\hline
\end{tabular}

\subsection{Key factor framework: Delphi analysis of expert responses}

A questionnaire survey was employed and targeted three cohorts of decision makers: civil service employees, academics, and industry professionals. Each cohort consisted of individuals who had 3-30 years of experience in their respective fields. A total of 22 questionnaires were distributed; 8 to civil service employees, 5 to academics in relevant fields, and 9 to industry professionals. Thirty valid questionnaires were retrieved, posting a response rate of $86 \%$. The respondents for the second stage were involved in the following fields: urban planning, environmental engineering, civil engineering and architectural engineering.

With reference to similar studies, this study used the average score and expert consensus (Gi) score as selection thresholds for the evaluation indexes. An evaluation index required an average score of 3.5 or above and a Gi score of $\geq 3.0$ to be considered a key factor. After the survey responses were analyzed, the evaluation indexes that did not meet these requirements were removed from the key factor framework. Two rounds of surveys were conducted, and the Delphi method was used to analyze the responses and calculate the corresponding scores. If the verification $(\mathrm{Zi})$ score of a factor exceeded 0 , it indicated expert consensus and the convergence of the factor scores (Wang et al. 2011). Accordingly, the proposed MCE framework was established for site selection evaluation. The results from the Delphi analysis were subsequently applied to the weighting of the evaluation indexes (Table 2).

According to the result of all experts evaluation, the revise of the evaluation indexes reducing the variable from 12 to 10 and from 36 to 31 follow: (1) The two evaluation indexes of " Pollution control "and "Energy resources" have be merged into the "Digitization".(2)The expert consensus score of "Government financial benefit" have be deleted, because of the score less than 3.5. (3) The evaluation index of "Expenditure ratios of collaborative projects" have be changed into the second level of "Sustainability" index. (4) The expert consensus score of "Implementation rate of smart or green buildings" have be deleted, because of the score less than 3.5. (5) Finally, the two evaluation indexes of "Site maintenance area" and "Employment growth rate attributable to digital management and training" have be reserved, because of the expert consensus score more than 3.6 in the first investigation. 
Table 2. Evaluation index selection by using the Delphi method.

\begin{tabular}{|c|c|c|c|c|c|c|c|}
\hline & & & Relat & ive importar & nce & $\mathrm{Zi}$ & $\mathrm{Gi}$ \\
\hline $\begin{array}{l}\text { Evaluation } \\
\text { dimension }\end{array}$ & Evaluation criterion & Evaluation index & $\begin{array}{l}\text { Maximum } \\
\text { score }\end{array}$ & $\begin{array}{l}\text { Minimum } \\
\text { score }\end{array}$ & $\begin{array}{l}\text { Average } \\
\text { score }\end{array}$ & $\begin{array}{l}\text { Verificati } \\
\text { on score }\end{array}$ & $\begin{array}{c}\text { Expert } \\
\text { consensus } \\
\text { score }\end{array}$ \\
\hline \multirow{6}{*}{ Environment } & \multirow{3}{*}{$\begin{array}{l}\text { Environmental site } \\
\text { conditions }\end{array}$} & Site location & 5 & 3 & 4.2 & 0.81 & 4 \\
\hline & & Site maintenance area & 5 & 1 & 3.4 & 1.38 & 3 \\
\hline & & $\begin{array}{l}\text { Level of environmental } \\
\text { intelligentization }\end{array}$ & 5 & 2 & 3.9 & 1.06 & 3.5 \\
\hline & \multirow{3}{*}{ Digitization } & $\begin{array}{l}\text { Digitization of environ- } \\
\text { mental monitoring }\end{array}$ & 5 & 2 & 4 & 1.25 & 3.5 \\
\hline & & $\begin{array}{l}\text { Digitization of passive en- } \\
\text { ergy conservation }\end{array}$ & 5 & 1 & 4.2 & 0.68 & 3 \\
\hline & & $\begin{array}{l}\text { Improvement in quality of } \\
\text { life through digitization }\end{array}$ & 5 & 2 & 4 & 1.06 & 3.5 \\
\hline \multirow{6}{*}{ Governance } & \multirow{2}{*}{ Improvability } & $\begin{array}{l}\text { Issues } \quad \text { concerning } \\
\text { sustainability } \\
\text { improvement }\end{array}$ & 5 & 2 & 4.1 & 0.93 & 3.5 \\
\hline & & $\begin{array}{l}\text { Issues concerning } \\
\text { intelligentization } \\
\text { improvement }\end{array}$ & 5 & 2 & 3.9 & 1.06 & 3.5 \\
\hline & \multirow{4}{*}{ Sustainability } & $\begin{array}{l}\text { Expenditure ratios of col- } \\
\text { laborative projects }\end{array}$ & 5 & 1 & 4.3 & 0.75 & 3 \\
\hline & & $\begin{array}{l}\text { Implementation of smart } \\
\text { building projects }\end{array}$ & 5 & 2 & 3.8 & 1.25 & 3.5 \\
\hline & & $\begin{array}{l}\text { Implementation of basic } \\
\text { smart infrastructure }\end{array}$ & 5 & 2 & 4 & 1 & 3.5 \\
\hline & & $\begin{array}{l}\text { Implementation of carbon } \\
\text { reduction and energy con- } \\
\text { servation }\end{array}$ & 5 & 1 & 3.7 & 1.31 & 3 \\
\hline \multirow{6}{*}{ Mobility } & \multirow{4}{*}{ Informationization } & $\begin{array}{l}\text { Mobile phone penetration } \\
\text { rate }\end{array}$ & 5 & 3 & 4.4 & 0.56 & 4 \\
\hline & & Wi-Fi coverage & 5 & 3 & 4.6 & 0.38 & 4 \\
\hline & & $\begin{array}{l}\text { Mobile broadband ( } 3 G \\
\text { and } 4 G \text { ) usage penetration } \\
\text { rate }\end{array}$ & 5 & 3 & 4.6 & 0.38 & 4 \\
\hline & & $\begin{array}{l}\text { Informationization } \\
\text { performance }\end{array}$ & 5 & 3 & 3.9 & 1.13 & 4 \\
\hline & \multirow{2}{*}{$\begin{array}{l}\text { Sustainable } \\
\text { transportation }\end{array}$} & $\begin{array}{l}\text { Public transportation } \\
\text { usage rate }\end{array}$ & 5 & 1 & 4.3 & 0.69 & 3 \\
\hline & & $\begin{array}{l}\text { Nonmotorized vehicle } \\
\text { usage rate }\end{array}$ & 5 & 2 & 4 & 1.06 & 3.5 \\
\hline
\end{tabular}




\begin{tabular}{|c|c|c|c|c|c|c|c|}
\hline & & $\begin{array}{l}\text { Renewable energy trans- } \\
\text { portation usage rate }\end{array}$ & 5 & 3 & 3.8 & 1.06 & 4 \\
\hline \multirow{6}{*}{ People } & \multirow{3}{*}{$\begin{array}{l}\text { Humanistic } \\
\text { qualities }\end{array}$} & Community cohesion & 5 & 3 & 4.5 & 0.5 & 4 \\
\hline & & Community identity & 5 & 3 & 4.3 & 0.63 & 4 \\
\hline & & Open-mindedness & 5 & 3 & 4.3 & 0.69 & 4 \\
\hline & \multirow{3}{*}{ Lifelong learning } & $\begin{array}{l}\text { Digital management and } \\
\text { training performance }\end{array}$ & 5 & 2 & 3.8 & 1.19 & 3.5 \\
\hline & & $\begin{array}{l}\text { Digital learning platform } \\
\text { penetration rate }\end{array}$ & 5 & 3 & 3.9 & 1.13 & 4 \\
\hline & & $\begin{array}{l}\text { Employment growth rate } \\
\text { attributable to digital } \\
\text { management and training }\end{array}$ & 5 & 1 & 3.4 & 1.44 & 3 \\
\hline \multirow{6}{*}{ Feedback } & \multirow{4}{*}{$\begin{array}{l}\text { Maintenance and } \\
\text { management } \\
\text { systems }\end{array}$} & $\begin{array}{l}\text { Environmental } \\
\text { monitoring performance }\end{array}$ & 5 & 2 & 3.9 & 1.13 & 3.5 \\
\hline & & $\begin{array}{l}\text { Information technology } \\
\text { application }\end{array}$ & 5 & 3 & 4.2 & 0.81 & 4 \\
\hline & & $\begin{array}{l}\text { Carbon reduction and en- } \\
\text { ergy conservation perfor- } \\
\text { mance }\end{array}$ & 5 & 2 & 3.4 & 1.56 & 3.5 \\
\hline & & $\begin{array}{l}\text { Self-liquidating perfor- } \\
\text { mance }\end{array}$ & 5 & 2 & 4.3 & 0.75 & 3.5 \\
\hline & \multirow{2}{*}{$\begin{array}{l}\text { Potential contribu- } \\
\text { tion to urban de- } \\
\text { velopment }\end{array}$} & $\begin{array}{l}\text { Site proximity to city cen- } \\
\text { ter }\end{array}$ & 5 & 2 & 4.1 & 0.88 & 3.5 \\
\hline & & Cultural diversity & 5 & 2 & 3.7 & 1.31 & 3.5 \\
\hline
\end{tabular}

\subsection{Analysis of factor weights: examination of expert responses through the AHP}

Weights were assigned to the evaluation dimensions, evaluation criteria, and evaluation indexes to reflect their relative importance in the MCE framework of smart city demonstration projects. The 12 evaluation criteria were reduced to 10, and the original 36 evaluation indexes were reduced to 31 . The evaluation criteria were paired with the evaluation dimensions and assigned weights. These weights were then referenced when the weights of the evaluation indexes were adjusted to optimize the MCDM model (Table 4).

Table 4. Analysis of factor weights for the MCE of smart city demonstration projects.

\begin{tabular}{|c|c|c|c|c|c|c|c|c|}
\hline $\begin{array}{l}\text { Evaluation } \\
\text { dimension }\end{array}$ & Weight & Evaluation criterion & & Weight & Evaluation index & $\begin{array}{l}\text { Original } \\
\text { weight }\end{array}$ & $\begin{array}{l}\text { Adjusted } \\
\text { weight }\end{array}$ & $\begin{array}{l}\text { Or- } \\
\text { der- } \\
\text { ing }\end{array}$ \\
\hline \multirow{3}{*}{$\begin{array}{l}\text { A } \\
\text { Environment }\end{array}$} & \multirow{3}{*}{0.186} & \multirow{3}{*}{$\begin{array}{l}\text { A1 } \\
\text { Environmental } \\
\text { conditions }\end{array}$} & \multirow{3}{*}{ site } & \multirow{3}{*}{0.116} & $\begin{array}{l}\text { A1-1 } \\
\text { Site location }\end{array}$ & 0.382 & 0.044 & 4 \\
\hline & & & & & $\begin{array}{l}\text { A1-2 } \\
\text { Site maintenance area }\end{array}$ & 0.251 & 0.029 & 19 \\
\hline & & & & & A1-3 & 0.367 & 0.034 & 13 \\
\hline
\end{tabular}


Level of environmental intelligentization

A2-1

$\begin{array}{lllll}\text { Digitization of environmental } & 0.293 & 0.027 & 23\end{array}$ monitoring

A2

Digitization

B1

Improvability

B2

Sustainability

C

Mobility

0.227

C1

Informationization
0.091

\section{A2-2}

Digitization of passive energy 0.280 conservation

\section{A2-3}

Improvement in quality of life 0.427 through digitization

B1-1

Issues concerning sustainability 0.489 improvement

0.092

B1-2

Issues

intelligentization improvement

\section{concerning $\quad 0.511$}

B2-1

$\begin{array}{llllll}\text { Expenditure ratios } & \text { of } & 0.236 & 0.032 & 16\end{array}$

collaborative projects

\section{B2-2}

$\begin{array}{lllll}\text { Implementation } & \text { of } & \text { smart } & 0.224 & 0.030\end{array}$

0.132 building projects

B2-3

Implementation of basic smart

0.321

0.043

infrastructure

B2-4

Implementation of carbon reduc- 0.219

0.029

20

tion and energy conservation

C1-1

0.101

Mobile phone penetration rate

$0.312 \quad 0.032$

15

C1-2

Wi-Fi coverage

$0.277 \quad 0.028$

21

C1-3

$\begin{array}{llll}\text { Mobile broadband (3G and 4G) } & 0.229 & 0.023 & 27\end{array}$

usage penetration rate

C1-4

Informationization performance

$\begin{array}{lll}0.182 & 0.019 & 29\end{array}$

C2-1

Public transportation usage rate

$0.526 \quad 0.037$

10
$\mathrm{C} 2-2$

0.069
Nonmotorized vehicle usage rate

0.264

0.018

30

C2-3

$\begin{array}{llll}\text { Renewable energy transporta- } & 0.210 & 0.015 & 31\end{array}$

tion usage rate

5

8

3

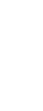




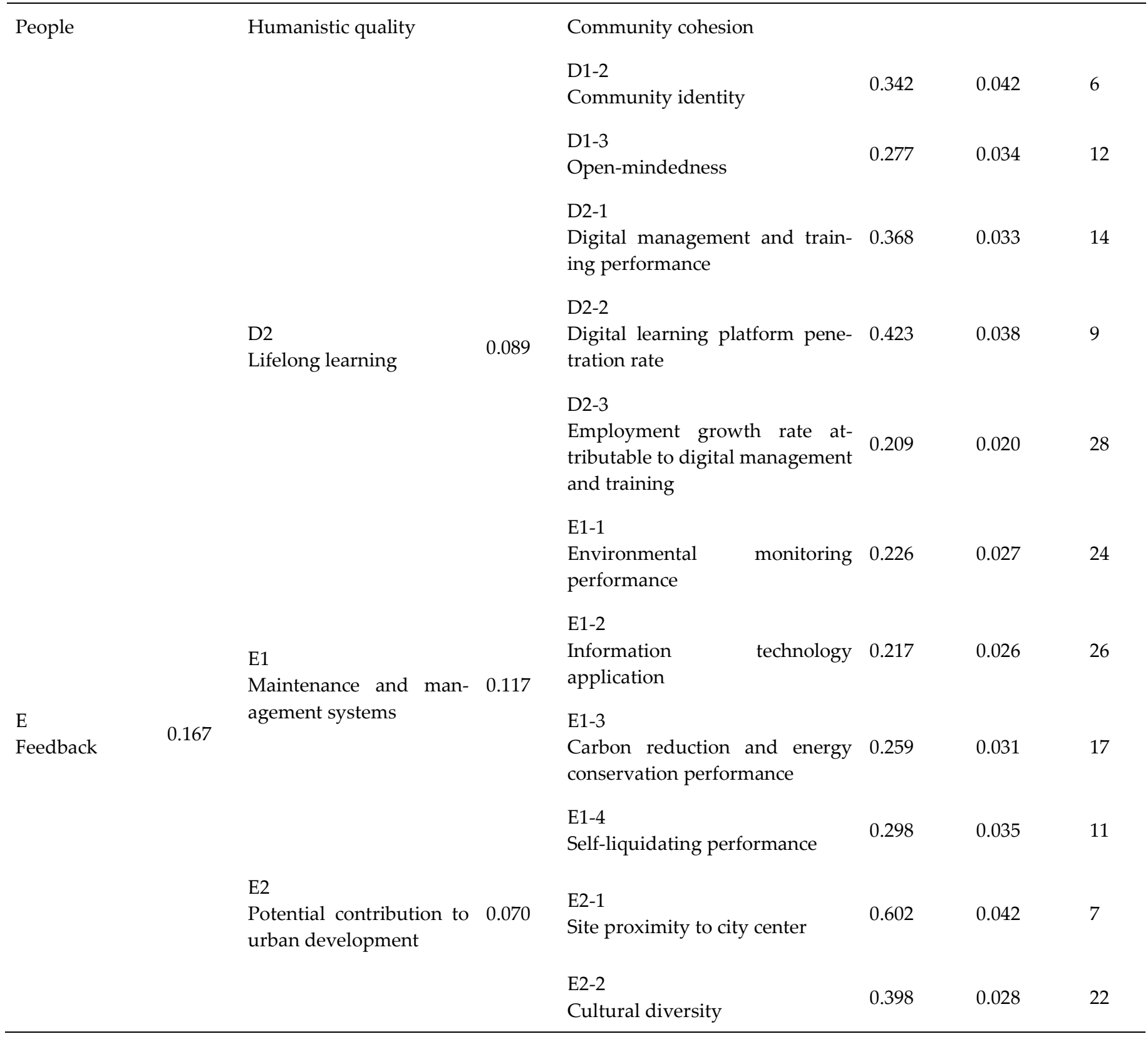

\section{Case studies of simulated MCE applications}

This study performed evaluation simulations at the following four sites: Taipower Smart Community, National Yunlin University of Science and Technology, Taichung Creative Cultural Park, and the Asia New Bay Area. The evaluation simulations were used to verify the feasibility of using the MCE model to assess smart city demonstration projects. Numerical data were also collected and used to evaluate site conditions, including with regard to resource availability. According to its performance, each site was reviewed and recommendations were formulated to facilitate its development into a smart community. From the MCE simulation, an original performance score and an adjusted score, both between 0 and 1, was generated for each site on the basis of the weights assigned according to evaluation criteria (Charts 1-4).

Chart 1. MCE performance of Taipower Smart Community site. 


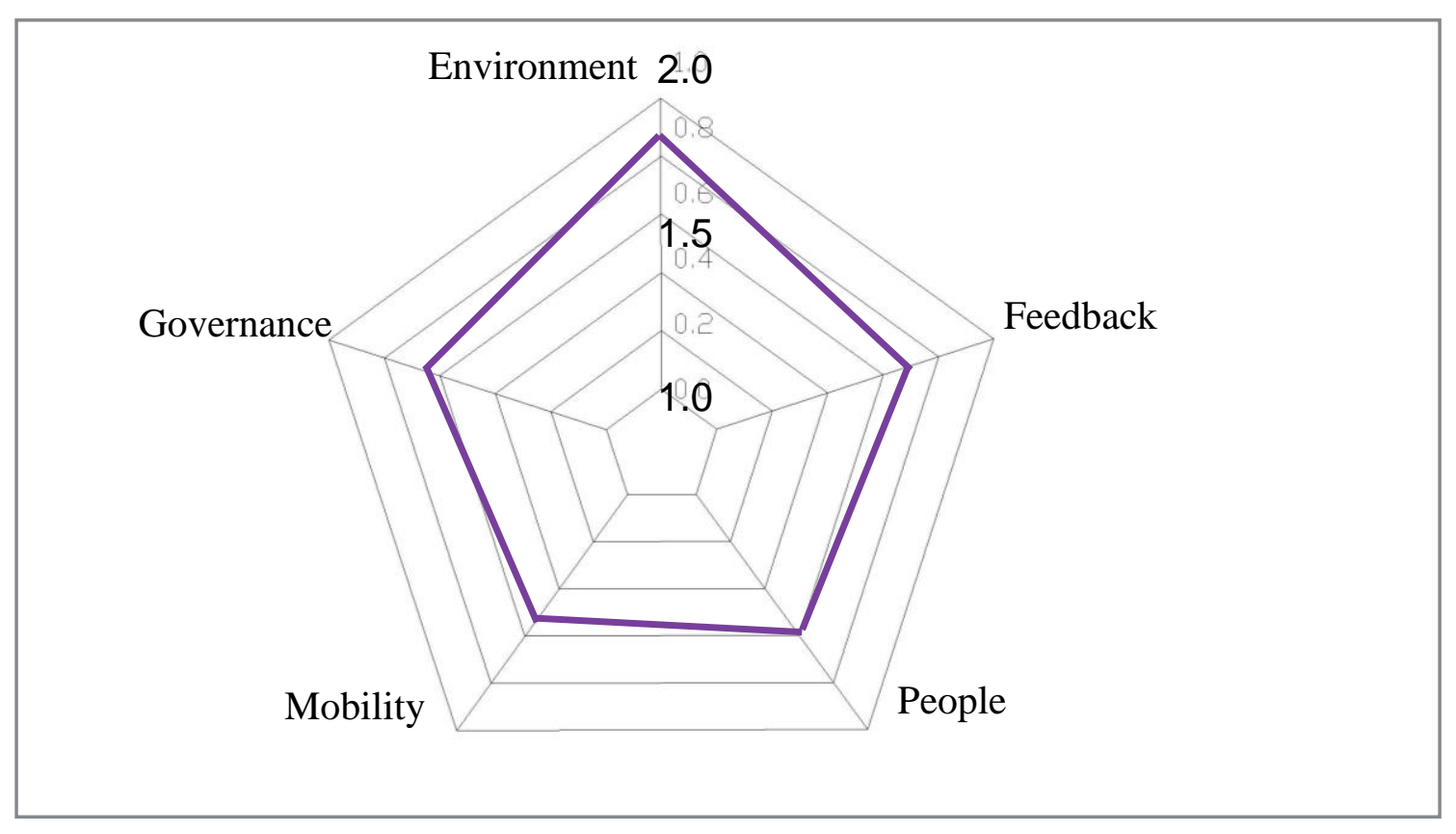

Chart 2. MCE performance of National Yunlin University of Science and Technology site.

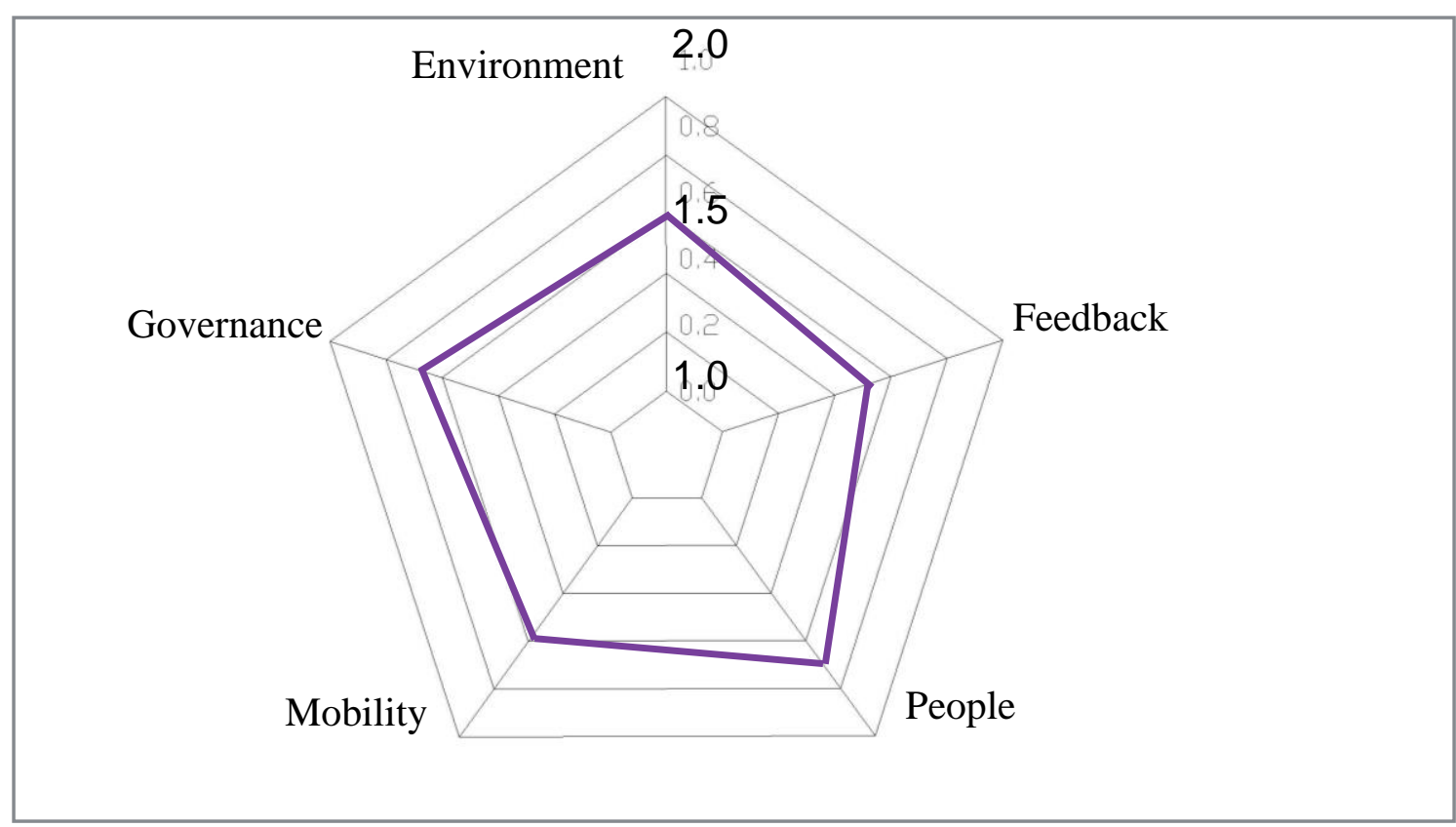


Chart 3. MCE performance of Taichung Creative Cultural Park site.

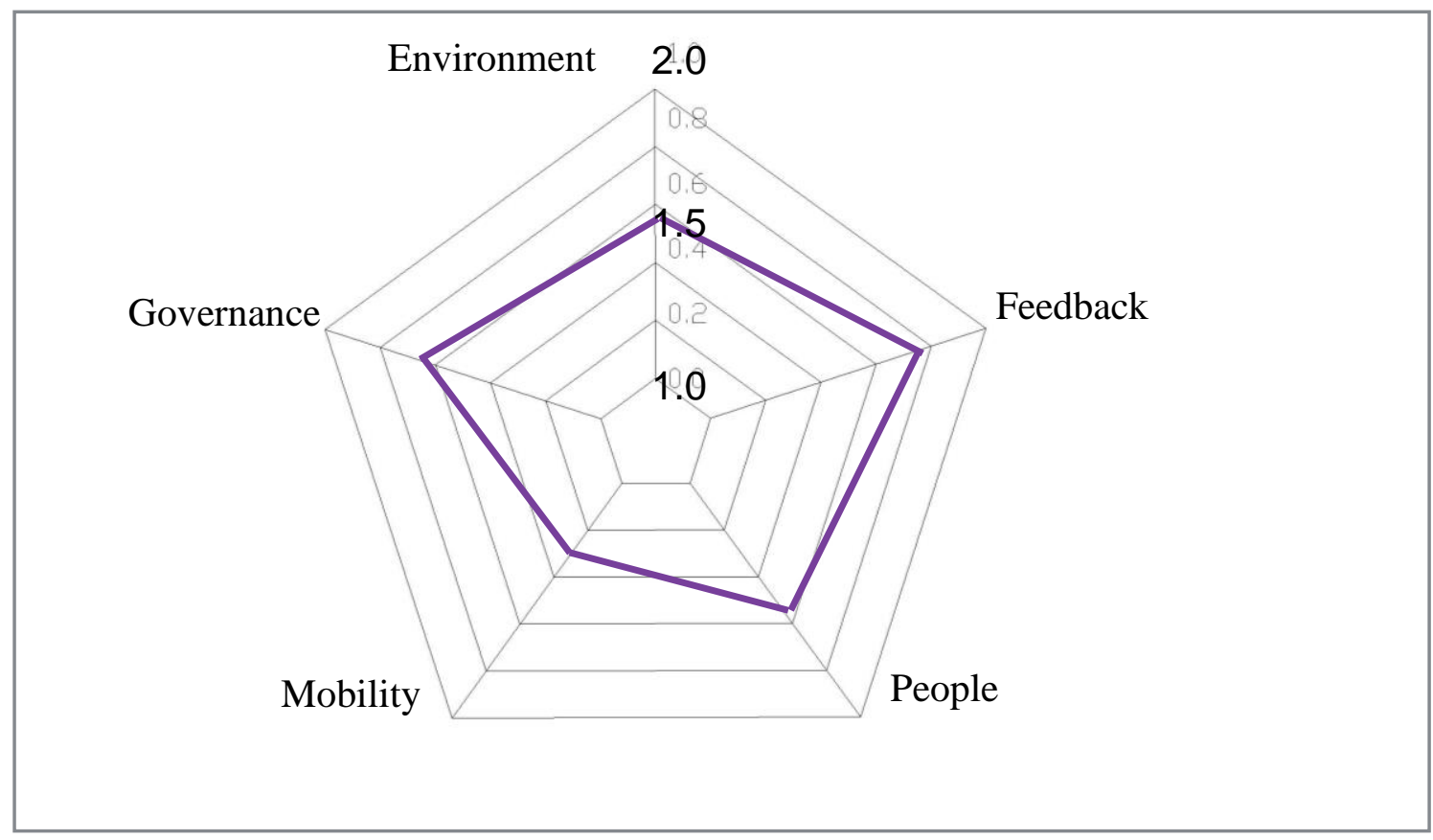

Chart 4. MCE performance of Asia New Bay Area site.

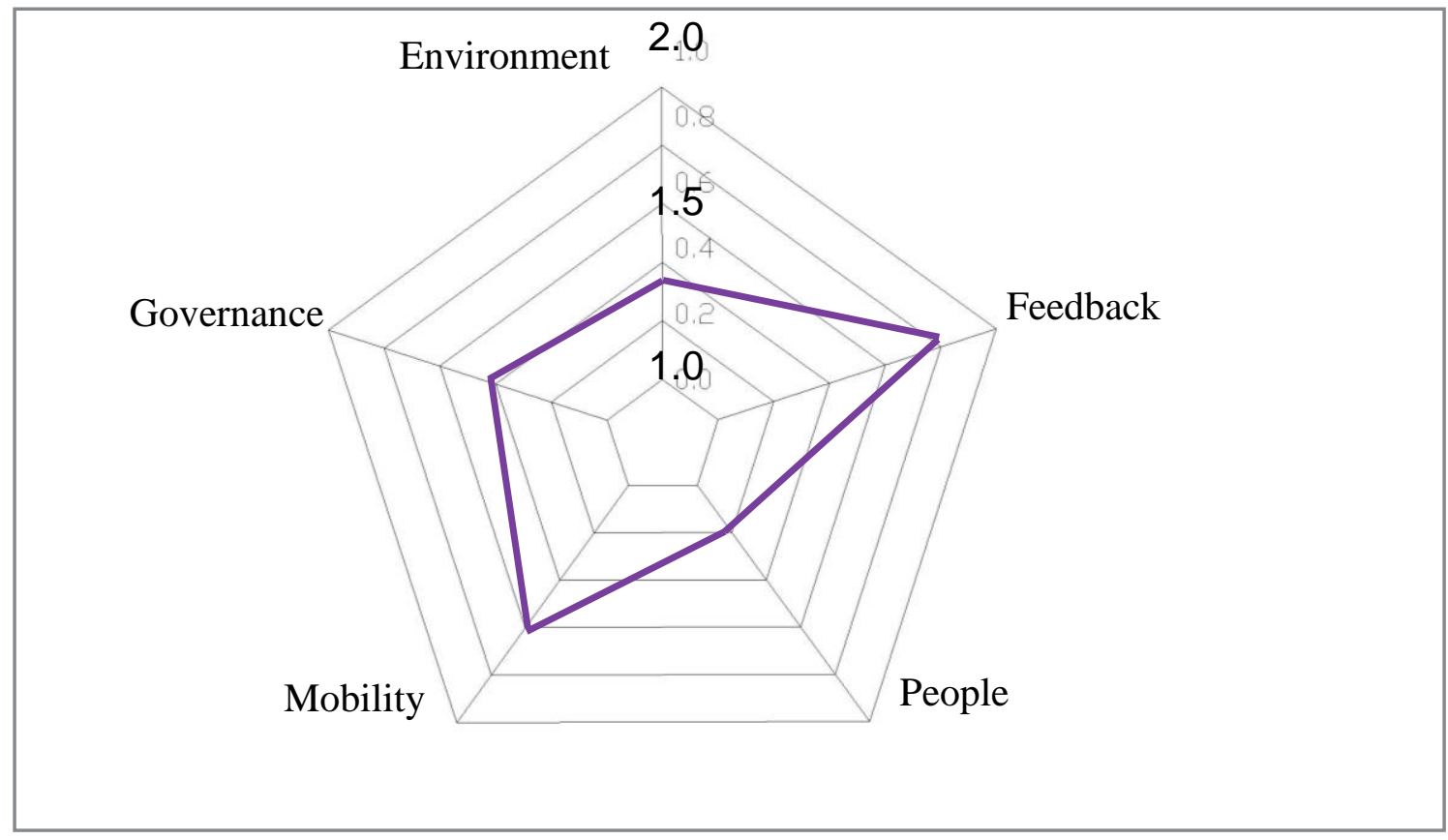

\section{Conclusion}

In Taiwan, some researchers argue that the current mechanism by which government subsidies are allocated for smart city demonstration projects warrants improvement. A comprehensive literature review determined that the development potential of smart cities should be prioritized in site selection for such demonstration projects. This study 
proposed an MCE model for smart city demonstration projects following a literature review and empirical analysis. The findings are expected to serve as a reference for future smart city-related projects. The key findings are summarized as follows:

\subsection{Inclusion of environment, governance, mobility, people, and feedback in the MCE of smart} city demonstration projects

Environment: The environmental dimension contained two evaluation criteria, namely "environmental site conditions" and "digitization." The evaluation indexes of "the environmental site conditions" were "site location," "site maintenance area," and "level of environmental intelligentization." The evaluation indexes of "digitization" were "digitization of environmental monitoring," "digitization of passive energy conservation," and "improvement in quality of through digitization."

Governance: The governance dimension contained two evaluation criteria, namely "improvability" and "sustainability." The evaluation indexes of "improvability" were "issues concerning sustainability improvement" and "issues concerning intelligentization improvement." The evaluation indexes of "sustainability" were "the expenditure ratios of collaborative projects," "implementation of smart building projects," "implementation of basic smart infrastructure," and "implementation of carbon reduction and energy conservation."

Mobility: The mobility dimension contained two evaluation criteria, namely "informationization" and "sustainable transportation." The evaluation indexes of "informationization" were "mobile phone penetration rate," "Wi-Fi coverage," "mobile broadband (3G and 4G) usage penetration rate," and "informationization performance." The evaluation indexes of "sustainable transportation" were "public transportation usage rate," "nonmotorized vehicle usage rate," and "renewable energy transportation usage rate."

People: The people dimension contained two evaluation criteria, namely "humanistic qualities" and "lifelong learning." The evaluation indexes of "humanistic qualities" were "community cohesion," "community identity," and "open-mindedness." The evaluation indexes of "lifelong learning" were "digital management and training performance," "digital learning platform penetration rate," and "employment growth rate attributable to digital management and training."

Feedback: The feedback dimension contained two evaluation criteria, namely "maintenance and management systems" and "potential contribution to urban development." The evaluation indexes of "maintenance and management systems" were" environmental monitoring performance," "information technology application," "carbon reduction and energy conservation performance," and "self-liquidating performance." The evaluation indexes of "potential contribution" to urban development" were "site proximity to city center" and "cultural diversity."

\subsection{Importance of evaluation indexes for the MCE of smart city demonstration projects}

In descending order, the weights of the 10 evaluation criteria are as follows: sustainability, humanistic qualities, maintenance and management systems, site environmental conditions, informationization, improvability, digitization, lifelong learning, potential contribution to urban development, and sustainable transportation. Therefore, the expert panels concluded that the consideration of sustainability, humanistic qualities, and maintenance and management systems (under the governance, people, and feedback dimensions, respectively) should be prioritized in site selection. Sustainable transportation had a lower weight, indicating its lower importance. Given that sustainable transportation was under the mobility dimension, it suggested that mobility constituted a less essential consideration in the early stages of site selection. This also demonstrated that high intelligentization was not a requirement for site selection. 
In descending order, the weights of the 31 evaluation indexes are as follows: issues concerning intelligentization improvement, community cohesion, issues concerning sustainability improvement, site location, implementation of basic smart infrastructure, community identity, site proximity to city center, improvement in quality of life through digitization, digital learning platform penetration rate, public transportation usage rate, selfliquidating performance, open-mindedness, level of environmental intelligentization, digital management and training performance, mobile phone penetration rate, expenditure ratios of collaborative projects, carbon reduction and energy conservation performance, implementation of smart building projects, site maintenance area, implementation of carbon reduction and energy conservation, Wi-Fi coverage, cultural diversity, digitization of environmental monitoring, environmental monitoring performance, digitization of passive energy conservation, information technology application, mobile broadband (3G and $4 \mathrm{G}$ ) usage penetration rate, employment growth rate attributable to digital management and training, informationization performance, nonmotorized vehicle usage rate, and renewable energy transportation usage rate. The higher weights of intelligentization improvement, community cohesion, issues concerning sustainability improvement, site location, implementation of basic smart infrastructure, and community identity indicated that the expert panels considered them more essential. These evaluation indexes corresponded to the following evaluation criteria: improvability, humanistic qualities, site environmental conditions, and sustainability. Less essential indexes corresponded to the evaluation criteria of informationization and sustainable transportation, both of which were under the mobility dimension. This once more indicated that the experts considered mobility less essential in the early stages of site selection, and that high intelligentization was not a requirement for site selection.

The analysis of survey responses revealed that the three expert panels concurred that high intelligentization was not an essential requirement for site selection. This consensus accords with the present premise that the development potential of smart cities should be prioritized in site selection.

\subsection{Development of an objective, quantifiable evaluation model using MCE simulations}

In descending order, the intelligentization performance of the simulation sites the first year of evaluation is as follows: Taipower Smart Community, National Yunlin University of Science and Technology, Taichung Creative Cultural Park, and the Asia New Bay Area. Their development potential is in reverse order; the Asia New Bay Area had the highest potential, followed by Taichung Creative Cultural Park, National Yunlin University of Science and Technology, and Taipower Smart Community. Taipower Smart Community, the Asia New Bay Area, Taichung Creative Cultural Park, and National Yunlin University of Science and Technology is the descending order of the projected benefits of the sites, as indicated in an analysis of their establishment durations and government funding ratios.

According to the simulation results, high intelligentization corresponded to the highest potential for becoming a smart community demonstration site (e.g., Taipower Smart Community). However, if such a community, such as National Yunlin University of Science and Technology, lacks long-term planning and effective management, it will not be a suitable demonstration site. If they lack basic smart infrastructure and have high goals for self-liquidation, and assuming rapid growth in intelligentization within the next 2 years and a high government funding ratio, sites - in this case, the Asia New Bay Area and Taichung Creative Cultural Park - can be projected to have the highest potential to become smart communities.

The results may serve as a reference to relevant units when determining the subsidies to be granted future smart communities in Taiwan. A multicriteria evaluation must comprehensively assess these factors to precisely inform the funding agency of the efficacy of the provided financial support, on the basis of which they can adjust or reallocate the financial support for the next fiscal year. Such an evaluation mechanism forms a virtuous 
cycle that encourages the participation of stakeholders (private-sector operators). The findings are expected to facilitate the selection of future smart community demonstration sites.

\section{References}

1. Annalisa Cocchia , 2014, Smart and Digital City: A Systematic Literature Review, Department of Economics, University of Genoa, Genoa ,Italy.

2. Architecture and Building Research Institute, Ministry of the Interior. 2015. Innovative Demonstration Field of Sustainable and Smart Community Application Notes and Guidelines, Taipei: published by Lo-Jing Wang .

3. Architecture and Building Research Institute, Ministry of the Interior. 2016. Innovative Demonstration Field of Sustainable and Smart Community Promotion Strategy and Legal Projects, Taipei: published by Lo-Jing Wang .

4. Batty, M. 2020. “Defining Smart Cities: High and Low Frequency Cities, Big Data and Urban Theory." In K. Willis, and A. Aurigi (eds.). The Routledge Companion to Smart Cities, London: Routledge.

5. Batty, M., K. W. Axhausen, F. Giannotti, et al. 2012. "Smart Cities of the Future." European Physical Journal: Special Topics 214 (1): 481-518. doi:10.1140/epjst/e2012-01703-3.

6. Chesbrough, H. W. 2003. Open Innovation: The New Imperative for Creating and Profiting from Technology. Cambridge, MA: Harvard Business School Publishing.

7. Dutton, W.H., Blumler, J.G. and Kraemer, K.L. 1987. Wired Cities: Shaping Future Communication. Macmillan, New York.

8. Dameri, R. P. 2014. Comparing Smart and Digital City: Initiatives and Strategies in Amsterdam and Genoa. Are They Digital and/or Smart? Smart City: 45-88. Publisher: Springer International Publishing

9. Dameri, R. P., and C. Rosenthal-Sabroux, eds. 2014a. Smart City: How to Create Public and Economic Value with High Technology in Urban Space. ISBN: 978-3-319-06160-3.

10. Edwards, W. 1977. "How to Use Multi-attribute Utility Measurement for Social Decision Making." IEEE Transactions on Systems, Man, and Cybernetics, SMC-7, pp. 326-340.

11. Edwards, W., F. H. Barron. 1994. "SMART and SMARTER: Improved Simple Methods for Multi-attribute Utility Measurement." Organizational Behavior and Human Decision Process 60 (3): 306-325.

12. Gassmann, O., and E. Enkel. 2004. “Towards a Theory of Open Innovation: Three Core Process Archetypes." Proceedings of the R\&D Management Conference, Lisbon, Portugal, 6-9 July.

13. Graham, S. and Marvin, S. 1999. "Planning cybercities: Integrating telecommunications into urban planning." Town Planning Review 70(1): 89-114

14. Gwo-Hshiung Tzeng 2002." Multicriteria selection for a restaurant location in Taipei", Hospitality Management 21 (2002) 171-187.

15. Hwang, Ching-Lai., and K. S. Yoon. 1981. "Multiple Attribute Decision Making". Lecture Notes in Economics and Mathematical Systems Volume 186. ISBN 978-3-642-48318-9.

16. Ishida, T. and Isbister, K. 2000. Digital Cities: Technologies, Experiences, and Future Perspectives. Springer. LNCS 1765

17. Institute for Information Industry. 2015. From Living Lab to Smart City, pp13-16, Taipei.

18. Institute for Information Industry,2014. Smart City Import Reference Manual, ISBN: 9789575815202, Taipei.

19. Komninos, N. 2002. Intelligent Cities: Innovation, Knowledge Systems and Digital Spaces. Routledge, London.

20. Kitchin, R. 2014. "The real-time city? Big data and smart urbanism", GeoJournal, 79(1): 1- 14.

21. Kitchin, R., Coletta, C., Evans, L. and Heaphy, L. (2018) Creating smart cities, Routledge, London. pp. 1-18.

22. Kandt, J., and M. Batty. 2021. Smart Cities, Big Data and Urban Policy: Towards Urban Analytics for the Long Run, pp2, Cities journal :www.elsevier.com/locate/cities.

23. Opricovic, S., 1998. Multicriteria Optimization in Civil Engineering. Faculty of Civil Engineering, Belgrade.

24. Shepard, M. 2011. Sentient City: Ubiquitous Computing, Architecture, and the Future of Urban Space. MIT Press, Cambridge, Mass.

25. Schuth, A., K. Balog, and L. Kelly. 2015. “Overview of the Living Labs for Information Retrieval Evaluation (LL4IR) Clef Lab 2015." Experimental IR Meets Multilinguality, Multimodality, and Interaction. Publisher: Springer, pp. 484-496. ISBN 978-3-319-24026-8.

26. T. L. Satty 1980. The Analytic Hierarchy Process: Planning Setting, Resource Allocation. New York, NY: McGraw-Hill.

27. Townsend, A. M. (2013). Smart cities: Big data, civic hackers, and the quest for a new utopia. Norton, New York: W. W.

28. Tsou, P. C. 2013. “A Comparative Study of Multiple Criteria Decision Making Techniques on Two Cases." Master Thesis, Department of Industrial Engineering and Management, Yuan Ze University, Taoyuan in Taiwan.

29. TU Wien (Rudolf Giffinger, Hans Kramar, Gudrun Haindlmaier, Florian Strohmayer). 2015. European Smart 4.0. Vienna University of Technology, Department of Spatial Planning, SRF - Centre of Regional Science, Vienna UT, $2007:$ 5-12.

30. Willis, K. and Augiri, A. 2018. Digital and Smart Cities. Routledge, London.

31. Wang, H. L., Y. F. Ho, Y. C., Huang, and C. I. Wu. 2011. “The Evaluation Framework of Eco-city-A Case Study in Taichung City." Journal of Architecture 75: 115-134. DOI: 10.6377/jA.201103.0008.

32. Zeleny, M. 1982. Multiple Criteria Decision Making. New York, NY: McGraw-Hill. 
Preprints (www.preprints.org) | NOT PEER-REVIEWED | Posted: 22 December 2021

doi:10.20944/preprints202112.0351.v1 